\title{
SOCIETY ADVOCACY COALITION IN PUBLIC DIALOGUE AS PUBLIC POLICY MAKING
}

\author{
Ramaditya Rahardian, Bintan Aulia Habibah \\ Master of Public Policy Program, Faculty of Social Science and Political Science, \\ Airlangga University Surabaya, Indonesia \\ ramaditya_rd@yahoo.co.id,bintanauliahabibah@gmail.com
}

\begin{abstract}
This article aimed to find out the role and interest of a society in a public dialogue as policy making in Bojonegoro District by observing theory review of Sabatier and Wible in Advocacy Coalition Framework (ACF). Furthermore, research in this article used research method of qualitative descriptive with technique of collecting data through observation, interview and documentation. Technique of determining informant used purposive sampling, then it changed to snowball sampling. Public dialogue is a common space between society between people/society and Government of Bojonegoro District to discuss the needs of people that became a public policy based on aspiration and society demands. The result of the research showed society coalition that succeeded influencing Government of Bojonegoro District in policy making.
\end{abstract}

Keywords: Coalition, Public Dialogue, Policy making, Advocacy Coalitions Framework.

\section{Introduction}

Government of Bojonegoro District is a role model in implementing deliberative democracy. Bojonegoro District has a program of forum between society and Bojonegoro District Government named forum dialog Jumat (Friday Dialogue Forum). Regent and vice-regent of Bojonegoro, Sutoyo and Setyo Hartono understand that in realizing good governance needs society involvement in policy making. Friday dialogue program is a political promise that regent of Bojonegoro will open Pendopo Malowati to all class of actors or stakeholders in Bojonegoro District. It is to reveal aspiration and issues. They are parts of policy advocacy. Examining more deeply, revealing aspiration and demands to maker or implementer of a policy is part of policy advocacy.

According to Young and Quinn (2002), Suharto (2004) in his book (Suharto, 2014) suggests some advocacy definitions, especially related to social policy analysis. In their view, advocacy is processes than involve some of political actions done by citizens to transform power relation. The aim of this advocacy is to achieve change of policy that has benefit for involved society in that process. Effective advocacy is conducted according to strategic plan and reasonable in time frame, whereas policy advocacy based on (Topatimasang, 2016) is an effort to improve or change public policy according to their will or interest that force to improvement or the change. Beside, concept of advocacy coalition framework (ACF) according to Sabatier and Jenkins Smith in (Fischer, 2007), it is a framework of policy making developed to maintain urgent policy issue. Sabatier and Wible in (Fischer, 2007) assume that individual in Advocacy Coalition Framework (ACF) uses some resources to develop 
strategy in order to affect policy through some sites/places. This resource comprises some elements such as (1) Formal legal authority for decision making, (2) public opinion, (3) information, (4) troops that can be mobilized, (5) financial resource (6) skilled leadership.

According to Weible in (Delgado, 2011) explains six resources to achieve the goal. It starts from formal legal authority or law access occurs when a member in coalition who is officials, legislators or judges gives the impression to a coalition with the access through political processes. This public opinion explain that when a coalition can obtain strong public support and it can give opinion that it is important to represent public interest. In that context, it enables to conduct change of rules if it is needed. The use of information in SCF is equated with weaponry used by coalition to support coalition membership, to influence public opinion, support their position with decision maker and refute the arguments from opposite coalition. Furthermore, in context of troop mobilization, it refers to help that is needed from general society, network and supportive ally in helping a coalition to achieve the target and success. Other important instrument in resource in ACF is financial resource and skill of leader. This instrument highly affects in implementation of policy advocacy. With financial resource they have, coalition an give political support to obtain sympathetic, obtain an access to legislator and public official, give research support that has potential to change policy process and affect public opinion and mobilize a coalition to move the support. Final, a skilled leader in ACF will strengthen membership by articulating coalition belief system in the name of coalition. The ability to express coalition belief can be used to attract additional resource for coalition.

Research about advocacy coalition has researched by many people such as (Wong, 2016) in which the article discusses about anti-incinerator protests in Guangzhou, China by observing framework of advocacy coalition to analyze dynamic between government of Guangzhou City and protesters. The second article is written by (Markard, Suter, \& Ingold, 2016) that discuss about gab within actor and coalition in energy policy in Swiss. The last article that discusses about framework of advocacy coalition is article from (Payan, 2017) in which the article discusses about the search of advocacy coalition, policy confidence,resource and strategy in debating menu label policy in California. Writing of this article has a novelty dimension of theoretical review in his writing because research about society advocacy coalition in Friday dialogue in Bojonegoro District has just discussed in partial theory review. Further article is article written by (Prianto,2013) that tries to see advocacy coalition in policy formulation in spatial plan in Makasar in period of 2010 - 2030. Furthermore, article of (Hess,2018) discusses about approach toward democracy study of energy that shows how framework used by intermediaries in integrating a energy-transition coalition in New York. Other article written by (Larry Maxwell,2015) discusses evaluating the success of achieving several non-profit organizations that focuss on cancer with the concept of advocacy. This writing strives to see approach of participation of Bojonegoro people by reviewing theory of Advocacy Coalitions Framework (ACF) 
revealed by Sabatier and Wible as the knife of analysis. However, this research only discusses about resource in Advocacy Coalition Framework (ACF).

\section{Research Method}

Research in article type of qualitative descriptive was defining a process of society advocacy coalition in Friday dialogue in Bojonegoro District in effort to urge the demands to become a public policy. Research site was conducted in Pendopo/ hall Malowapi Bojonegoro District where people reveal aspiration and demand to government in order to affect policy maker to meet what they want. Beside, collecting the data was conducted through observation, interview and documentation study. Determining the informants was carried out with purposive technique sampling and snowball sampling. The result of the data was then processed with source (data) of triangulation technique.

\section{Discussion}

This discussion will discuss more about the resources used in the community advocacy coalition of Bojonegoro Regency by reviewing the theories from the advocacy coalition framework (ACF). As for the resources used by the advocacy coalition from the community group of Bojonegoro Regency among others are as following:

\section{a. Formal Legal Authority in Decision Making}

The legal authority in the community advocacy coalition in Friday dialogue in Bojonegoro Regency is done based on joint discussion and dialogue with the Government of Bojonegoro District to digging and gathering information regarding the needs and demands of the people that will be realized in a formulation of public policy later. It can be seen from the Friday dialogue program that the roles of some stratums and society groups such as agricultural groups, farm groups and the general public network have been able to affect the policy makers, in this case the Government of Bojonegoro Regency by presenting data in the fields of education, livestock, agriculture and public works. Activities that are routinely performed on Friday in the Malowopati pavilion of Bojonegoro Regency always get attention from each coalition group to ask the interests of every group.

\section{b. Public Opinion}

Through the opportunity of Friday dialogue, people from various stratums of groups who gathered in the Malowopati Hall conveyed public opinions to the Regent and all heads of Regional Work Units (SKPD) to communicate by expressing constructive ideas, concept, desires, complaints, and criticisms to make what policy should be taken by the Government of Bojonegoro Regency to solve public issues in the area of Bojonegoro Regency, the existing public opinion that develops in the community of Bojonegoro Regency which is often become a complaint and aspiration 
of the coalition group is around the issue of agriculture, livestock, education and public works and social problems.

\section{c. Information}

With the holding of Friday dialogue that held regularly, it can be said that the information of this friday dialogue program has been running effectively and is known by several stratums of individuals and community groups in Bojonegoro Regency. Moreover, this Friday dialogue information is often announced through a local radio namely the private owned FM radio that is radio Madani and the Government Bojonegoro Regency radio, that is Malowopati FM radio to discuss about what issues will be discussed in Friday dialogue every week. With this information, some stratums and community groups can be moved and participate in a regular Friday dialogue program that is held by the Government of Bojonegoro Regency to deliver their aspirations and demands to the Government of Bojonegoro Regency by looking at the issues that will be discussed in the forum of Friday public dialogue.

\section{d. Groups that can be mobilized}

Society which consists of several elements and existing community groups always mobilizes their existing groups to deliver their aspirations, ideas, concepts and criticisms to the Government of Bojonegoro Regency so that it becomes a policy that is suitable with their wishes, as for the groups and stratums who are always present in Friday dialogue program among others are the general public, agricultural groups, farmer groups and disability groups. Every individual and groups that involved in the Friday dialogue always brings the results of the study and data used to be delivered at the forum, more and more groups can attend public dialogue forums on Friday by a certain group, this makes the government of Bojonegoro District Government feel necessary and importance to consider and make policies which favor the individual communities and groups of people who demand them.

\section{e. Financial Resources}

Friday dialogue initiated by the Government of Bojonegoro Regency encouraged the participation from various stratums and groups of people in Bojonegoro Regency to attend, as it was known that the community in this program did not use huge costs in delivering their aspirations, ideas, concepts and demands as well as criticisms to the Government of Bojonegoro Regency. The individual community or groups of people who come to the forum of friday dialogue participate voluntarily or invite by their groups, this is in order that the policies issued by the policy makers are in accordance with the wishes or desire of those who press and pressure them.

\section{f. Skilled leadership}

There is always a leader of community group who represents the interests of his group in this friday dialogue. In the moment of Friday dialogue, some leaders or 
group representatives from various elements of society always use an interactive dialogue mechanism by trying to lobby, propose something, and criticize the Government of Bojonegoro Regency in order for the policies later are in accordance with the desire of various elements of the Bojonegoro community group. The leader of the existing group is always expert in coordinating the mass, presenting data in the field, as well as speaking skills and lobbying the public policy makers.

\section{g. The results of the Bojonegoro Community Advocacy Coalition}

Some series of advocacy performed by Bojonegoro community groups such as agriculture groups, livestock groups and the general public in Friday dialogue program have succeeded in making a policy in favor of various groups and elements of the Bojonegoro community, examples of policies that have been advocated by various elements and groups of people among others are: (1) Farmer Cropping Pattern Policy, (2) Development of Forest Road Areas, (3) Control of Street Vendor, (4) RASTRA or Raskin Policy, (4) Regent Regulation Number 18 Year 2012 Regarding Association of Water-Using Farmers.

\section{Conclusion}

The writing of this article discussed about advocacy coalition of Bojonegoro community in Friday dialogue by using theoretical approach of Sabatier and Weible in advocacy coalition framework (ACF), from the overall series of community advocacy in Friday dialogue, the series of advocacy successfully provide positive results with the issuance of several policies by the Government of Bojonegoro Regency which is suitable with the desire and wishes from the individual community or group of people who urged them. This article gives new perspective with a dimension of theoretical review because the previous studies only discussed about participation.

\section{Acknowledgement}

We are very grateful to the Regional Government of Bojonegoro Regency as well as various elements of individuals or community groups who collaborated on the information provided for resources in the research of this article.

\section{References}

Delgado, J. . (2011). Coalition Stability In California's marine life protection act policy development process: an advocacy coalition framework anlysis. Collage of Business And Public Management Departement Of Public Administration. University Of La Verne. California.

Fischer, F. (2007). Handbook Of Public Policy Analysis Theory, Policy, And Methods. London: CRC Press.

Hess, D. J. (2018). Energy democracy and social movements: A multi-coalition 
perspective on the politics of sustainability transitions. Energy Research and Social Science, 40(January), 177-189.

Larry Maxwell, G. (2015). The state of advocacy in cancer. Gynecologic Oncology, 139(3), 573-579.

Markard, J., Suter, M., \& Ingold, K. (2016). Socio-technical transitions and policy change - Advocacy coalitions in Swiss energy policy. Environmental Innovation and Societal Transitions, 18, 215-237.

Payan, D. D. (2017). Advocacy coalitions involved in California's menu labeling policy debate: Exploring coalition structure, policy beliefs, resources, and strategies. Social Science \& Medicine, 177, 78-86.

Prianto, A. L. (2013). Model of Advocacy Coalitions in the Formulation of Spatial Plan Policy of Makassar in 2010-2030. Bisnis \& Birokrasi Journal, 20(3), 163-170.

Suharto, E. (2014). Analisis Kebijakan Publik, Panduan Praktis Mengkaji Masalah Dan Kebijakan Sosial. Bandung: Alfabeta.

Topatimasang, R. (2016). Mengubah Kebijakan Publik Panduan Pelatihan Advokasi. Yogyakarta: Insist Press.

Wong, N. W. M. (2016). Advocacy Coalitions and Policy Change in China: A Case Study of Anti-incinerator Protest in Guangzhou. Voluntas, 27(5), 2037-2054. 